\title{
The Relathionship of Community Knowledge About Filariasis by Drinking Medicine of Totally Treatment Program at the Third Year in Puskesmas Arbais, Sarmi Regency
}

\author{
Yunita Kristina ${ }^{1}$, Korinus Suweni ${ }^{2}$, Iryanti $^{3}$ \\ ${ }^{1}$ Bachelor of Nursing Program, Cenderawasih University, Papua, Indonesia \\ ${ }^{2}$ Nursing Diploma Program, Health Politechnic of Jayapura, Papua, Indonesia \\ ${ }^{3}$ Bachelor of Nursing Program, Cenderawasih University, Papua, Indonesia
}

\begin{abstract}
Elephant's foot or filariasis, is a disease caused by a worm infection filaria transmitted through mosquito bites. Government's efforts in the Elimination of filariasis through mass treatment program. This program has been implemented in the Sarmi Regency from 2013. Data from Puskesmas Arbais Regency Sarmi found some wayward society against a mass treatment program fialriasis. The purpose of the study to find out the relationship public knowledge about drinking behaviour against filariasis drugs treatment programme in the third year of filariasis mass work-area of Puskesmas Arbais Sarmi Regency.This research uses descriptive correlation design with crossectional study. The population in this research is all people in the region of Puskesmas Arbais with a total sample of as much as 55 respondents obtained by purposive sampling technique. Data obtained using questionnaires and analyzed using chi square. The research results obtained that knowledge societies in the region of Puskesmas Arbais about filariasis knowledge lacking. Filariasis mass drug drinking behavior in the region of Puskesmas Arbais is less (58.5\%). No relationship public knowledge about drinking behaviour against filariasis drugs treatment programme in the third year of filariasis mass work-area of Puskesmas Arbais Sarmi Regency.
\end{abstract}

Keywords: Knowledge, The Behavior of drinking medicine, Filariasis

\section{Background}

Filariasis elephantiasis or elephant's foot disease, is a disease caused by filaria worm infections are transmitted through mosquito bites. The disease is widespread in rural and urban areas. It can be attacking everyone without age and gender. In the world there is 1.3 billion people are at risk of contracting the disease of the foot of an elephant in more than 83 countries and $60 \%$ of cases are in South East of Asia.

The incidence of filariasis in Indonesia by 2013 as much 11,903 sufferers increasing in 2014 and 2015 12,714 as much as 14,932 sufferers. This indicates an increase in cases of the disease filariasis in Indonesia. Papua Province in the last three years the incidence of filariasis 2013 as much 1,346 sufferers, 2014 and 20151,346 as much as much as 1,184. The data showed a decrease in the incidence of filariasis.

The efforts made the Government in treatment filariasis case was initiated by WHO since 1999, in 2000 strengthened with the decision by the WHO declared "The Goal of the Global Elimination of Lymphatic Filariasis as a Public Health Problem by the Year 2020". The agreement of the Government of the Republic of Indonesia based on the WHO in 1999 and 2000. Filariasis elimination acceleration program will continue to be attempted up to the year 2020 . As the initial phase carried out the first five-year accelerated beginning in 2010-2014. The goal of the program is all regencies/cities are endemic in areas of Eastern Indonesia have done POMP filariasis in 2014
Indonesia eradicate filariasis as part of the global filariasis elimination through the two pillars of activity: decided the chain transmission of filariasis Mass Drug prevention by administering (POMP) filariasis in endemic areas once a year for five years in a row; preventing and limiting disability case management with filariasis. Until 2014 based on finger blood survey, as many as 235 recident/city have been mapped as filariasis endemic areas. However, the new 142 recident/city that carries out Mass Drug Prevention (POMP) filariasis. As many as 42 counties/cities have been implementing Mass Drug Prevention (POMP) filariasis a minimum of five consecutive years with coverage of treatment above $65 \%$. coverage of the Bulk Drug Prevention (POMP) filariasis over the last four years is on the rise, from $37.7 \%$ in 2011 be $73.9 \%$ in 2014.

Sarmi Regency filariasis elimination report by 2015 of 12 hometown from the survey data of the number of finger blood checked as much as 1,158 people with a positive blood count suffer from filariasis as much as 175 people. While on a work-area Puskesmas Arbais filariasis positive undiagnosed as many as 6 people $(2.71 \%)$ of the population as much as 221 people.

The practice of the community in the prevention, control and treatment of filariasis in Majalaya subdistrict have a significant relationship (p-value 0.001) towards compliance of the community for taking the drug. Compliance with medication does not stand on its own, this condition is inextricably linked with the support of the human resources 


\section{International Journal of Science and Research (IJSR) \\ ISSN (Online): 2319-7064}

Index Copernicus Value (2015): 78.96 | Impact Factor (2015): 6.391

(HR) good health workers, cadres, cross-sector and incessant promotion through various media.

Mass treatment Clinics in the region Arbais first year (2013) and mikroflilaria (MF) examination rate of $15.4 \%, 2014$ with Mf rate of $15.6 \%$ and by 2015 with Mf rate amounted to $17.3 \%$ of the targets set in the amount of $95 \%$. This shows still lack drug consumption behavior of the community in filariasis.

Research objectives to find out "the relationship public knowledge About Drinking Behaviour Against Filariasis Drugs treatment programme in the third year of Filariasis Mass work-area Puskesmas Arbais Sarmi Regency"

\section{Method of Research}

Type of this research is a descriptive correlation design with crossectional study, i.e. a variable measured at the same time (at one time approach) at a time i.e. linking knowledge society against filariasis mass treatment programs third year working area of Puskesmas Arbais Sarmi Regency.

\section{Population and Sample}

The overall population is a research object or objects being researched. The population in this research is all people in the region Arbais of Puskesmas as much as 95 head of families by the number of inhabitants as much as 221 people. The sample is a portion of a population that is considered representative to represent the population. The number of as many as 53 people were obtained by means of purposive sampling techniques.

\section{Result}

\section{Respondent Characteristic}

Table 1: Distribution of respondents based on age, gender, education and occupation in PuskesmasArbais June 2016 (n

\begin{tabular}{|l|c|c|}
\hline \multicolumn{1}{|c}{ Characteristic } & Frequency(n) & $(\%)$ \\
\hline 1. age & & \\
Young Adult & 14 & 26,5 \\
Middle Young & 20 & 37,7 \\
Old mature & 19 & 35,8 \\
\hline 2. Sex & & \\
Men & 27 & 50,9 \\
Women & 26 & 49,1 \\
\hline 3. Education & & \\
No Education & 8 & 15,1 \\
Elementary & 27 & 50,9 \\
Junio & 14 & 26,4 \\
Senior High & 4 & 7,5 \\
\hline 4. Job & & \\
No Job & 28 & 52,8 \\
Farmer & 15 & 28,3 \\
Fisherman & 3 & 5,7 \\
Private & 6 & 11,3 \\
Goverment staf & 1 & 1,9 \\
\hline
\end{tabular}

Based on table 1, shows that most aged are on the range of age between $31-45$ years $(37.7 \%)$, elementary education $(50.9 \%)$, not working $(52.8 \%)$.

\section{Knowledge of Filariasis}

Table 2: Distribution of respondents based on knowledge of the treatment of filariasis in the region Arbais, the Clinic June $2016(n=65)$

\begin{tabular}{|c|c|c|}
\hline Characteristic & Frequency(n) & $(\%)$ \\
\hline Less & 35 & 66 \\
\hline Well & 18 & 34 \\
\hline Total & 53 & 100 \\
\hline
\end{tabular}

Based on table 2, shows that the knowledge of respondents about the most knowledgeable filariasis less, i.e. as many as 35 people $(66 \%)$ and good knowledge of as many as 18 people (34\%).

\section{Filariasis Mass Drug Drinking Behavior}

Table 3:Distribution of respondents based on behavioural medication at the clinic work area Arbais, June 2016 ( $\mathrm{n}=$ 65)

\begin{tabular}{|c|c|c|}
\hline $\begin{array}{c}\text { Drinking medicine } \\
\text { behavior }\end{array}$ & $\begin{array}{c}\text { Frequency } \\
\text { (n) }\end{array}$ & $(\%)$ \\
\hline Less & 24 & 45,3 \\
Well & 29 & 54,7 \\
\hline Total & 53 & 100 \\
\hline
\end{tabular}

Based on table 3, showing that the behavior of most filariasis is taking medication less, i.e. as many as 38 people (58.5\%) and behavioral medication either as many as 27 people $(41.5 \%)$.

\section{The relationship of knowledge against filariasis drugs drinking behavior}

Table 4: The distribution relation knowledge against filariasis drugs drinking behavior in Puskesmas Arbais June $2016(n=65)$

\begin{tabular}{|c|c|c|c|c|c|c|}
\hline \multirow{2}{*}{ Knowledge } & \multicolumn{4}{|c|}{$\begin{array}{c}\text { Behavior of dribking } \\
\text { medicine }\end{array}$} & \multirow{2}{*}{ p-value } & $R P$ \\
& \multicolumn{2}{|c|}{ Less } & \multicolumn{2}{|c|}{ Well } & & \\
& & & \\
& $\mathrm{n}$ & $\%$ & $\mathrm{n}$ & $\%$ & & \\
\hline Less & 20 & 57,1 & 15 & 42,9 & \multirow{2}{*}{0,033} & 2,571 \\
Well & 4 & 22,2 & 14 & 77,8 & & $(1,034-6,392)$ \\
\hline
\end{tabular}

Table 4, showed that respondents who have less knowledge against filariasis drugs less drinking behavior as much as 20 people $(57.1 \%)$ and behavioral medication filariasis good as much as 15 people (42.9\%). While the respondents have knowledge well against filariasis drugs less drinking behavior as much as 4 people $(22.2 \%)$ and behavioral medication filariasis good as much as 14 people $(77.8 \%)$. The chi square test results obtained the value of $\rho=0.033<$ (0.05, so declared Ho accepted, which means that there is a relationship of public knowledge about drinking behaviour against filariasis drugs treatment programme in the third year of filariasis mass work-area Clinics Sarmi Regency Arbais depends on the value of $\mathrm{RP}=2.571$ who interpreted that respondents who have knowledge of less risky behaviors take medication less of 2.571 times greater compared to respondents who have good knowledge 


\section{International Journal of Science and Research (IJSR) \\ ISSN (Online): 2319-7064}

Index Copernicus Value (2015): 78.96 | Impact Factor (2015): 6.391

\section{Discussion}

\section{Public knowledge about Filariasis}

The results of this research were obtained that knowledge of the respondents in the region the most Arbais Clinics about filariasis have less knowledge (66\%), while respondents who have good knowledge (34\%). These results indicate that respondents in knowledge work-area Clinics Arbais is still lacking.

Low level of knowledge of respondents working in the area of Puskesmas Arbais in terms of the level of public education. Of the 53 respondents who examinedwith education elementary $(50.9 \%)$ and respondents who do not as much school $15.1 \%$. While the high school educated respondents only 4 persons $(7.5 \%)$. This is in accordance with the theory of Prayoto (2014), that the higher education of a person, so the more easily to accept information so that more and more also for knowledge, instead of less education will hamper the development of a person's attitude towards values that are introduced. Education is needed to get the information, e.g. things that support the health so it can improve the quality of life.

Sarmi Regency Health Office in the elimination filariarisis program was implemented starting in the 2013 including a work in the area of public health Arbais, by providing treatment of filariasis mass that had previously been done promotif efforts to the community. But lack of knowledge can be caused working area Clinics Arbais entered in the region are isolated because of the difficult access and its territory far from the city. From the results of these studies also note that respondents who work most are farmers and fishermen, so that at the time of the execution of the promotif, the community were working in the fields or looking for fish.

Thus the respondents less of knowledge in the region Arbais, the Clinics because of lack of access to information about filariasis, in addition to the low respondent education and geography working area Clinics Arbais. While good knowledge by the respondent because getting information about filariasis, as well as the affordability of access to medical services.

Knowledge is lacking on this research because it does not know a risky environment against filariasis such as Bush, where mosquito breeding mosquitoes, because it does not know the agent of transmission of disease by mosquitoes, prevent of filariasis drugs made through the efforts made and the affected foot elephant (filariasis). The results of this research are no different in MajalayaSubdistrict village of Bandung Regency that low public knowledge about the transmission of disease prevention efforts, as well as filarisis.

\section{Filariasis Mass Drug Drinking Behavior}

The results of this research were obtained that behavioral medication filariasis respondents in work-area Clinics Arbais is less people (58.5\%) and behavioral medication (41.5\%). It showed half of respondents did not comply with appropriate medication dispensing stages filariasis..

As has been previously disclosed that repsonden most of the work as pentani and fishermen, so the behavior of taking medication less well done. This can occur because mass dispensing services is limited to one post a remedy, so that the communities that House much of the distance towards access services increasingly difficult to come to the post service of the drug. However, if the society has a good knowledge about the dangers of filariasis and have awareness about the benefits of filariasis mass treatment will have a good behaviour towards health. It also found that as much as $41.5 \%$ had good behavior in the bulk drug of filariasis.

Behavioral medication is lacking by people other than the affordability of health services who dwells in a place, so that people aren't getting medications, particularly a community that are working in the fields or looking for fish.

\section{The relationship of public knowledge about Filariasis Against Drug Treatment Program Drinking behavior of Bulk Filariasis}

The research results obtained that there are relationship public knowledge about drinking behaviour against filariasis drugs treatment programme in the third year of filariasis mass work-area Clinics Arbais Regency Sarmi $(\rho=0.033<$ (0.05), in which the respondents have less knowledge against filariasis drugs less drinking behavior (57.1\%), while respondents who have knowledge of good against filariasis drugs good drinking behavior $(77.8 \%)$

The results of this study also found that respondents who have a good knowledge, but has less comsump drug of filariasis due to not obtaining the drug, while respondents who have less knowledge but has a good behavior in taking medication, because obtaining the drug.

Lack of knowledge and leads to less comsump drug behavior can be caused that health workers are less actively involved in collaboration with community leaders and cadres in an effort promotif. The officer just give health education on communities within easy reach or who arrive in the post. Therefore, it is expected the officer actively involved in collaboration with community leaders and cadres in the promotif as well as administering drugs directly to the people who take the drug do not come. Support cadres, community leaders and health workers is urgently needed for the success of filariasis elimination in terms of dissemination of information or knowledge to the community.

Knowledge is the result of "know", this happens after sensing someone do to a specific object. Most human knowledge is obtained through sensing the eyes and ears. Related thereto in accordance with the theory put forward by Roger in Notoatmodjo, that behavior based knowledge will be more lasting than that is not based on knowledge. Of that knowledge is essential to the formation of capital one's actions and most communities have a high level of knowledge about the disease filariasis.

\section{Implication}

The behavior of taking medication less may result in the Elimination of filariasis be failed. Therefore, health workers

\section{Volume 6 Issue 7, July 2017 www.ijsr.net}




\section{International Journal of Science and Research (IJSR) \\ ISSN (Online): 2319-7064}

Index Copernicus Value (2015): 78.96 | Impact Factor (2015): 6.391

are expected to team up with local community leaders and cadres in the grant of extension as well as the granting of a remedy for people who do not come through the local cadres who previously had been given training on the mechanism of treatment of filariasis.

\section{Summary and Suggestion}

\subsection{Summary}

Based on the results can be summed up as follows: knowledge society in the region of Arbaisfilariasis Clinic has the most knowledge are lacking. Filariasis mass drug drinking behavior in the region of PuskesmasArbais is less $(58.5 \%)$. No relationship public knowledge about drinking behaviour against filariasis drugs treatment programme in the third year of filariasis mass work-area of PuskesmasArbaisSarmi Regency $(\rho=0.033<(0.05)$.

\subsection{Suggestion}

1) For health services and clinics Sarmi Regency Arbais For health workers should provide guidance such as filariasis program drug schedule as well as the prevention of fialriasis on a regular basis to the community by selecting the right time as well as active and engaged in collaboration with community leaders and cadres. Give medications directly to the community, without having to wait for the community to come to the post cure, given the geographical conditions by involving cadres who give medications directly to the public, especially at night, so the time of dispensing, to immediately drink.

2) For Nursing Education Institution As consideration for educational institutions so that it can be applied as one of health promotion using media leaflet against filariasis prevention behavior.

3) Researchers further to the next so that researchers can conduct research related to the granting of education as well as health promotion using audiovisual media, individually and in groups. It also can link between the characteristics of respondents by number incidence of filariasis and the factors that affect disease of filariasis.

4) For the community to expect the public to be able to play an active role in filariasis prevention efforts with regular medication filariasis on the schedule specified. In addition to expect people to further enhance the action mainly to wear mosquito nets while sleeping the night, don't hang your used clothes behind the door or wall, stockpiling goods secondhand that can hold rain water and wear the jacket, trousers and insect repellent when active at night

\section{References}

[1] Agustianingsih, Dina (2013) Praktek Pencegahan Filariasis. Jurnal KesehatanMasyarakat.

[2] Ahdy M. G. R. (2015) HubunganPengetahuan Dan SikapTentangPencegahanFilariasisDenganPraktekMinu mObatDalam Program PemberianObatMasalPencegahan (Pomp) FilariasisKelurahanKuripanKertoharjo Kota Pekalongan. http://www.unnes.co.id. diakses 2 Juni 2016.
[3] Alamsyah, D (2014). Pilar Dasar Ilmu Kesehatan Masyarakat. Yogyakarta :NuhaMedika.

[4] ArikuntoS (2010). ProsedurdanPendekatanPenelitian. RinekaCipta, Jakarta.

[5] Astuti E. P (2013) Analisis Perilaku Masyarakat Terhadap Kepatuhan Minum ObatFilariasis di TigaDesa Kecamatan MajalayaKabupaten Bandung Tahun 2013, Volume 24, No 4, Desember 2014, hlm. 199-208.

[6] Depkes RI (2006) PerawatanKesehatanMasyarakat. Depkes RI, Jakarta.

[7] Dinkes Prov. Papua (2015). ProfilKesehatan Papua, 2015.

[8] Dinkes Kabupaten Sarmi (2015). Profil Kesehatan KabupatenSarmi.

[9] Fitriani (2010). PromosiKesehatan. EdisiPertama, GrahaIlmu, Yogyakarta.

[10] HandayanidanSuryani (2010) KamusLengkapBahasa Indonesia Girillmu, Surabaya.

[11] Juriastuti (2013). FaktorRisikoKejadianFilariasis Di KelurahanJatiSampurna.

DepartemenKesehatanLingkungan,

FakultasKesehatanMasyarakat, Universitas Indonesia. (online) htttp://www.fk_ui.co.id. diakses 20 Maret 2016.

[12] Kesumah (2010). BukuPanduanDukungan, Perawatan, danPengobatanKomprehensif HIV/AIDS, PusatinformasiIlmiah, DepartemenIlmuPenyakitDalam FK Unpad, RS. Dr. HasanSadikin, Bandung.

[13] Kemenkes RI (2013). Informasi Pengendalian Penyakitdan Penyehatan Lingkungan. Dirjen Pengendalian PenyakitdanPenyehatanLingkungan. Jakarta :Kemenkes RI.

[14] Kemenkes RI. (2015). RencanaNasional Program AkselerasiEliminasiFilariasis di Indonesia. SubditFilariasis\&SchistomiasisDirektorat P2B2, Ditjen PP\&PL. Jakarta.

[15]Listiyarini, F (2015)HubunganPengetahuan Dan SikapTentangPencegahanPenularanFilariasisDenganKo ndisiFisikLingkunganKelurahanKuripanKertoharjo KotaPekalongan. http://www.unnes.co.id. diakses 2 Juni 2016.

[16] Maryam S (2014). PromosiKesehatan. EGC, Jakarta.

[17] Mubarak. (2011). PromosiKesehatanUntukKebidanan. SalembaMedika, Jakarta

[18] Notoatmodjo, S (2010). PromosiKesehatanMasyarakat. RinekaCipta, Jakarta.

[19]— (2011). KesehatanMasyarakat, IlmudanSeni. RinekaCipta, Jakarta.

[20]_ (2012). MetodePenelitianKesehatan. RinekaCipta, Jakarta.

[21]Prayoto, (2014). Teori, Sikap \& Perilakudalam Kesehatandilengkapicontohkuesioner. Yogyakarta :NuhaMedika.

[22] Panduprokjo, (2014). TeoriPengetahuan. http://www.kompasiana.com. diakses 18 Mei 2016

[23] Purwantyastuti, (2015). Pemberian Obat Massal Pencegahan (POMP). BuletinJendelaFilariasis di Indonesia. ISSN 2087 - 1546.

[24] Rusmanto. (2013) Faktor-Faktor Yang Mempengaruhi Sikap Dan Perilaku Masyarakat Terhadap Kepatuhan Minum Obat Anti Filaria di Rw II Kelurahan Pondok Aren.http://www.uin.co.id. diakses 2 Juli 2016.

[25] Santoso. (2014) PengaruhPromosiKesehatan TerhadapPengetahuan,Sikap Dan Perilaku Masyarakat 


\section{International Journal of Science and Research (IJSR) \\ ISSN (Online): 2319-7064}

Index Copernicus Value (2015): 78.96 | Impact Factor (2015): 6.391

TentangFilariasis. http://www.unnes.co.id. diakses 2 Juni 2016.

[26] Soedarto. (2011) BukuAjarParasitologiKedokteran, SagungSeto, Jakarta.

[27] Sugiyono. (2013) MetodePenelitianManajemen. Bandung :Alfabeta.

[28] Suparyanto. (2012) Faktor - fakltor yang mempengaruhikepatuhan. http://www.suparyanto wordpress.com. diakses 2 Juni 2016.

[29] Sutanto, I (2009), ParasitologiKedokteran, BalaiPenerbit UI, Jakarta.

[30] Sutanto, (2013). ParasitologiKedokteran Ed. 2, BalaiPenerbit UI, Jakarta.

[31] Swarjana. (2013) MetodologiPenelitianKesehatan. Andi, Yogyakarta.

[32] Taufik. (2011). Asal - UsulPengetahuan. http://www.ipb.co.id. diakses 18 mei 2016

[33] UtamiN. W

PengaruhPromosiKesehatanTentangFilariasisTerhadapS ikapMasyarakatDalamUpayaPencegahanPenyakitFilaria sis Di Daerah Pantura Kabupaten Subang. http://www.umudsurakarta.co.id. diakses 2 Juni 2016.

[34] Widoyono. (2008) Penyakit Tropisepidemiologi, Penularan, Pencegahandan Pemberantasan, Erlangga, Semarang.

[35]ZulkoniA (2011). Parasitologi. NuhaMedika, Yogyakarta. 